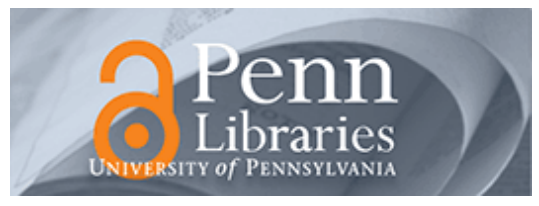

University of Pennsylvania ScholarlyCommons

\title{
Immigration Policy as Family Language Policy: Mexican Immigrant Children and Families in Search of Biliteracy
}

Sarah Gallo

Nancy H. Hornberger

University of Pennsylvania, nancyh@gse.upenn.edu

Follow this and additional works at: https://repository.upenn.edu/gse_pubs

Part of the Education Commons

\section{Recommended Citation}

Gallo, S., \& Hornberger, N. H. (2017). Immigration Policy as Family Language Policy: Mexican Immigrant Children and Families in Search of Biliteracy. International Journal of Bilingualism, http://dx.doi.org/ $10.1177 / 1367006916684908$

This paper is posted at ScholarlyCommons. https://repository.upenn.edu/gse_pubs/417

For more information, please contact repository@pobox.upenn.edu. 


\title{
Immigration Policy as Family Language Policy: Mexican Immigrant Children and Families in Search of Biliteracy
}

\author{
Abstract \\ Aims and objectives/purpose/research questions: \\ In this article we draw upon the ethnography of language planning and policy (LPP) to examine the \\ complexities of how young Latino children with a recently deported parent engage with family language \\ policies within their routine interactions. We explore the following questions. (1) How do US elementary \\ school-aged children engage with, resist, and refashion family language and literacy policies alongside \\ their parents in the face of parental deportations to Mexico? (2) How do children's and parents' \\ experiences with monoglossic ideologies of schooling in the USA and Mexico shape family LPP and \\ migratory decisions?
}

\section{Design/methodology/approach:}

The data come from a three-year ethnography on Mexican immigrant fathers and their elementary schoolaged children conducted within the context of heightened deportations.

\section{Data and analysis:}

We focus on the case of eight-year-old Princess following her father's deportation to examine how she articulated awareness of their counterpoint lives as she engaged in LPP alongside her mother.

\section{Findings/conclusions:}

Our findings reveal the unintended language education consequences of immigration policy as well as the complex ways that children discursively contribute to family LPP and migration decisions.

\section{Originality:}

This article uniquely highlights the complex interplay between immigration policy and LPP in the daily lives of mixed status Mexican immigrant families and the active roles that children play in shaping family language policy and migratory decisions.

\section{Significance/implications:}

We illustrate how children orient to monoglossic schooling ideologies as they prepare for and contest the possibilities of transnational schooling in Mexico and how limited opportunities to develop dynamic bilingualism or biliteracy in US schools shape families' decisions. We argue that educational policy and classroom practices that open up ideological and implementational spaces to dynamically develop both languages are needed to better prepare children-especially those from undocumented families within a context of unprecedented deportations-for educational success on both sides of the border.

\section{Keywords}

Family language policy, transnational schooling, biliteracy, Mexican immigrant, ethnography of language policy

\section{Disciplines \\ Education}


Immigration policy as family language policy: Mexican immigrant children and families in search of biliteracy

Sarah Gallo (The Ohio State University) and Nancy H. Hornberger (University of

Pennsylvania)

Corresponding Author:

Sarah Gallo

The Ohio State University

222 A Ramseyer Hall

29 W. Woodruff Avenue

Columbus, $\mathrm{OH} 43210$

gallo.85@osu.edu

215.595.4122 


\title{
Immigration policy as family language policy: Mexican immigrant children and families in search of biliteracy
}

Keywords: Family language policy; transnational schooling; biliteracy; Mexican immigrant; ethnography of language policy

\begin{abstract}
Aims and Objectives/Purpose/Research Questions

In this article we draw upon ethnography of Language Policy and Planning [LPP] to examine the complexities of how young Latino children with a recently deported parent engage with family language policies within their routine interactions. We explore the following questions: 1) How do U.S. elementary school-aged children engage with, resist, and refashion family language and literacy policies alongside their parents in the face of parental deportations to Mexico?; and 2) How do children's and parents' experiences with monoglossic ideologies of schooling in the U.S. and Mexico shape family LPP and migratory decisions?
\end{abstract}

\section{Design/Methodology/Approach}

The data come from a three-year ethnography on Mexican immigrant fathers and their elementary school aged children conducted within a context of heightened deportations.

\section{Data and Analysis}

We focus on the case of 8-year-old Princess following her father's deportation to examine how she articulated awareness of their counterpoint lives as she engaged in LPP alongside her mother.

\section{Findings/Conclusions}

Our findings reveal the unintended language education consequences of immigration policy as well as the complex ways that children discursively contribute to family LP and migration decisions.

\section{Originality}

This article uniquely highlights the complex interplay between immigration policy and language planning and policy (LPP) in the daily lives of mixed status Mexican immigrant families and the active roles that children play in shaping family language policy and migratory decisions.

\section{Significance/Implications}

We illustrate how children orient to monoglossic schooling ideologies as they prepare for and contest the possibilities of transnational schooling in Mexico and how limited opportunities to develop dynamic bilingualism or biliteracy in U.S. schools shape families' decisions. We argue that educational policy and classroom practices that open up ideological and implementational spaces to dynamically develop both languages are needed to better prepare children - especially those from undocumented families within a context of unprecedented deportations — for educational success on both sides of the border. 
Over styrofoam trays filled with pizza and cartons of milk in the school cafeteria, second-grader Alexis shared with his friends, also from Mexican immigrant families, how his family might move to Mexico — a country he had never been to- the following year. As he began to paint an idyllic picture of his imagined life in his family's hometown near Acapulco_-living in a larger house with a pool near the beach-Princess began to warn him “you won't be able to speak English there if you move back" and Ben emphasized that he'd even have to write in Spanish in school. Loretta remarked, "I hate Spanish," which ended Alexis' descriptions of his imagined childhood in Mexico (Field Note (FN) 12/14/10). This was a typical conversation among children from Mexican immigrant families in this study in Marshall, Pennsylvania. Evident in their routine talk were the ways that they-as members of transnational families with roots and potential educational futures across geopolitical borders - developed a "contrapuntal awareness" of "lives inhabitable in some other space and time" (Dick, 2013, p. 412; see also Said, 2000). In this interaction it is clear that they were not only imagining potential childhoods in Mexico, but also articulating stances on those imagined lives, such as a desirable life on the beach for Alexis. There are also hints of children's monoglossic ideologies in relation to biliteracy: Not only did they imagine that an English-dominant child like Alexis would no longer be able to speak English in Mexico, they also positioned Spanish writing in school as alarming and undesirable. This brief interaction provides a glimpse into how these children's articulations of counterpoint lives and biliteracy intertwine with immigration, language policy, and transnational family decision-making. 
No one at this lunchtime conversation was concretely considering relocation to Mexico. Three months later, however, these issues became more imminent for Princess when her father was stopped by local police officers for dropping a soda can, sent to Immigration and Customs Enforcement (ICE), and eventually deported to Mexico. Princess' father's deportation meant difficult decisions regarding family separation across geopolitical borders or repatriation to Mexico. Children's educational futures were a primary factor in family decisions, and Princess' family worried that she would not have the academic literacy in Spanish nor the experiential resources to succeed in Mexican schools. In the face of her father's deportation and the tangible reality that they might move to Mexico, Princess' shifting stances on her imagined childhood, schooling, and language practices were regularly inflected in routine interactions.

Here we explore the interplay between immigration policy and language planning and policy (LPP) in the daily life of a mixed status Mexican immigrant family with young children. Focusing on routine interactions within a single immigrant family provides a window into the dynamic and diverse perspectives that members bring to daily interactions as they engage in educational and familial work (cf. Mangual Figueroa, 2014). We examine the case of Princess and her family through a lens of ethnography of LPP to understand the ways children engage with the intersectionalities of deportationbased immigration practices and family language policies. We seek to highlight how young children can serve as agentive social actors and contribute to family language policy and migration decisions as they negotiate their own self-positioning across institutional settings (Orellana, 2009). We explore the complexities of how this child 
engages with family language policies through her stances toward imagined lives, languages, and schooling in Mexico and the US.

Through the case of Princess' family, we explore the following interrelated questions: 1) How does a U.S. elementary school-aged child engage with, resist, and refashion family language and literacy policies alongside her parents in the face of parental deportations to Mexico?; and 2) How do families' experiences with monoglossic ideologies of schooling in the U.S. and Mexico shape their LPP and migratory decisions? We argue that educational policies and schools must open up ideological spaces for valuing multilingualism and implementational spaces for enacting fluid and dynamic multilingual practices, voices and identities (Hornberger 2002, 2006) in order to better prepare children - especially those from undocumented families within a context of unprecedented deportations in the US - for educational success on both sides of the border.

In the following sections we first describe the context of immigration status and transnational schooling and the ethnography of language policy with special attention to ideological and implementational spaces for biliteracy. We then describe the town of Marshall and our study participants and design. Our findings reveal the unintended language and literacy education consequences of immigration policy as well as the complex ways that children discursively contribute to family language policy and migration decisions. In the final section, we discuss the educational and policy implications of this research.

\section{Immigration Status \& Transnational Schooling}


In 2011 the United States deported an unprecedented 391,953 foreign-born people (Preston, 2012), including 90,000 Mexican nationals with U.S-citizen children (Wessler 2012). Since 2008, new immigration programs such as Secure Communities and 287(g) have enabled local law enforcement to request proof of U.S. documentation and contact Immigration and Customs Enforcement (ICE) when they have stopped an individual for any type of infraction (Kohli, Markowitz, \& Chavez, 2011). Although positioned as programs to remove "dangerous criminals," in practice they have led to the deportation of many nonviolent offenders (Kohli et al., 2011). Today's “deportation regime” (De Genova, 2010)—in which undocumented immigrants are increasingly targeted and deported for minor infractions-deeply shapes Latino immigrants' lives. The effects of these immigration practices are experienced not just by those who are deported, but by everyone who lives with the daily possibility of deportation for themselves or their loved ones (Gallo, 2014; Mangual Figueroa, 2014; Suárez-Orozco, Yoshikawa, Teranishi, \& Suárez-Orozco, 2011). This impacts immigrants' lives across institutional contexts including schools: It is estimated that 5.5 million children in the U.S. live in families with undocumented immigrants (Chaudry et al., 2010).

On the Mexican side of the border, repatriated students' schooling realities are under-considered and under-researched (Hamann, Zúñiga, \& Sánchez-García, 2010). Yet children with U.S. schooling are increasingly enrolling in Mexican schools and the number of Mexicans repatriating has more than doubled in recent years (Passel, Cohn, \& González-Barrera, 2012, p. 8). Some evidence suggests that children with U.S. schooling experiences in Mexican schools do not fare well as there is limited consideration in Mexico's national curriculum to support repatriated students and their diverse linguistic 
and bi-national resources (Hamann \& Zúñiga, 2011). Little is known about how families navigate decisions regarding repatriation and early research has shown that children appear to have limited agency in family migration decisions (e.g., Sánchez-García, Hamann, \& Zúñiga, 2012) whereas others highlight the choices children were given by their caretakers (e.g., Dreby, 2010). Through careful attention to how a young child and her mother engage with immigration policies, bilingualism, and educational possibilities through an ethnography of LPP framework, this article helps reveal the nuanced ways children shape family migration decisions in the face of parental deportations.

\section{Ethnography of LPP, Biliteracy, and Ideological and Implementational Spaces}

The ethnography of language policy entails new methodological, conceptual, and critical infusions into the study of language planning and policy (LPP), arguably representing a paradigmatic shift in the field (Blommaert, 2013). With roots going back to the 1980s (e.g. Hornberger, 1988), the ethnographic approach to studying language policy implementation in context illuminates the creative and complex ways that actors including policymakers, communities, families and individuals take up, ignore, and sometimes resist language policies (Hornberger \& Johnson, 2011). Drawing on critical

LPP perspectives (Canagarajah, 1999; Cooper, 1989; Jaffe, 1999; Ruiz, 1984; Schiffman, 1996; Tollefson, 1991), the ethnography of LPP makes visible and explicit the interplay between the hegemonies of policy and the power of language policy actors (Johnson, 2013), uncovering indistinct voices and unintended consequences of LPP and highlighting possibilities for "transforming lives through language practices" 
(Hornberger, 2013, p. 118). This perspective informs our focus here on the complexities of Latino children's navigation of language policies and migration.

Family language policy studies represent part of the LPP move toward greater attention to "micro-level, face-to-face interactional" activities in language planning (Cooper, 1989, p. 38). Here we are interested in uncovering the ideologies and practices that play into children's and parents' decisions toward achieving biliteracy for childrendecision-making by transnational families who construct their lives, identities and communities — real and imagined — across geopolitical borders (King \& Rambow, 2012, p. 400). Our data are collected in a Pennsylvania town, and many of the focal children had never physically been to Mexico. Yet families' histories created a transnational community: from parents' upbringings in Mexico, to regular communication with family members residing in Mexico, to potential futures in Mexican towns and schools. As parents were increasingly deported for minor infractions, families were actively constructing their lives and identities across the Mexico-U.S. border. Our focus and approach are consistent with recent trends in family language policy research that include a greater focus on minoritized, multilingual and transnational families in which attention is given to children's shaping of family language policy (Fogle \& King, 2013).

Ethnographic research on LPP in general and language education policy (LEP) in particular has contributed to the growing questioning in sociolinguistics and applied linguistics of a monoglossic view of language as a fixed category, in favor of a view of language practices as heteroglossic, fluid and multilingual (Blackledge \& Creese, 2014; Makoni \& Pennycook, 2007). Yet educational policy and practice in U.S. schools remain largely aligned with a monoglossic view of language, pushing bilinguals to assimilate to 
an idealized monolingual norm (in each language) rather than building on their dynamic bilingualism - the fluid language practices in which they engage to make meaning and communicate (García, 2009). Ironically, this holds true not only in monolingual education, but in most bilingual education contexts as well, a tendency further exacerbated by restrictive language policies embodied in No Child Left Behind and standards-based educational reforms (Hornberger, 2006; Escamilla, 2006; Flores \& Schissel, 2014; Gándara \& Hopkins, 2010; Menken, 2008). Meanwhile, schools in Mexico likewise are not designed to meet the needs of a transnational population (Hamann \& Zúñiga, 2011). Here we probe these tensions and explore alternative policy possibilities for transnational families whose children's fluid and heteroglossic linguistic identities are ill-served by monoglossic language education policies in the two national contexts they navigate.

In particular, we employ ethnographic language policy research as "a means for exploring how varying local interpretations, implementations, negotiations, and perhaps resistance [do or do not] pry open implementational and ideological spaces for multilingual language education" (Hornberger \& Johnson, 2007, p. 511). Ideological spaces opened up by policies may carve out implementational spaces for multilingual educational practice, but it is also true that implementational spaces carved out from bottom up classroom practice may wedge open new ideological spaces (Hornberger, 2006); here we explore whether family language policy decision-making might also serve as implementational wedge in the face of closed-down spaces for multilingual education. We look at how a child and family struggle to make choices for their children's schooling in the face of subtractive bilingual schooling contexts (Valenzuela, 1999), where explicit 
ideologies and implementational practices are that bilingual learners replace their home language with the standardized national societal language (be it English in the U.S. or Spanish in Mexico). Additive bilingual schooling contexts in which a second language is added to the learner's repertoire, as in maintenance, two-way and immersion programs, are not among the implementational options available for the transnational families we look at here. Further, additive bilingualism, when understood only as double monolingualism - equal competence in two languages, is based on monoglossic language ideologies that may marginalize the fluid language practices of bilingual transnational communities (Flores \& Schissel, 2014; García, 2009; Heller, 1999).

We understand biliteracy broadly as "any and all instances in which communication occurs in two (or more) languages in or around written material" (Hornberger, 1990, p. 213), occurring in today's globalized world within mobile multilingual repertoires in contexts that are not only local but also simultaneously translocal and global. In these spaces, individuals' biliteracies develop across languages and oral-written, receptive-productive skills in complex ways including backtracking and criss-crossing as they draw on fluid, multimodal communicative practices (media) and engage with a range of text/discourse contents spanning dominant, decontextualized, literary genres and styles as well as minoritized, contextualized, vernacular ones (cf. Hornberger, 2003). From this continua of biliteracy perspective, government, classroom, and family language policies that "envision and incorporate students' mobile, multilingual language and literacy repertoires as resources for learning" (Hornberger \& Link, 2012, p. 274) might best prepare children for educational success on both sides of the border. 
We are particularly interested in family language acquisition planning as families dynamically prepare for and contest the possibilities of children's transnational schooling in Mexico and the U.S. We look at the ways that a family prioritizes the importance of biliteracy development to prepare their children for schooling in the U.S. and Mexico and how they grapple with the monoglossic ideologies embedded in both countries' schooling practices as they seek to provide opportunity and incentive for their children's acquisition of biliteracy. We highlight the ways that Princess engages with, resists, and refashions family language policies through her everyday talk, and how these discursive processes contribute to family migratory decisions.

\section{Setting and Methods}

This article draws on data from a larger three-year ethnographic study that investigated how seven Mexican immigrant fathers' participation shapes and is shaped by their children's elementary schooling. The setting was Marshall, Pennsylvania, a town of approximately 35,000 people that has become home to thousands of Latino (predominantly Mexican) immigrants over the past two decades, an increase from 3\% to $28 \%$ of the town's population. Marshall took a relatively inclusive approach to the growing Latino immigrant community until a policy shift in 2011 which deeply impacted children's lives and learning as Mexican immigrant men in particular were systematically detained and deported for minor infractions (See Gallo, 2014).

Latino student enrollment in schools similarly showed an increase from $2 \%$ to

25\% from 1987-2011, with a large concentration in the lower grades. The focal school for this study, Grant Elementary, served 400 students in grades K-4 with similar numbers of 
African American and Latino students. Teachers were primarily white, middle-class women who spoke only English. Grant was an English-medium school and did not offer bilingual education.

Data collection involved ethnographic fieldwork and video recording of routine activities over the course of the 2008 -2011 school years in families' homes and students' school. Home-based data collection entailed regular participant observation of routine interactions, interviews with parents and children, and bi-monthly home-based videorecordings and playback sessions, providing a window into ways family members engaged in routine talk related to language policy, immigration practices, and family migration. Weekly school-based participant observations and video-recordings within two focal classrooms and interviews conducted with educators provided a window into how students, teachers, and families engaged with ideologies regarding language and learning_-both local and contrapuntally imagined.

Most of the families from this study were mixed-status families in which younger family members had documentation while others did not and the deportation regime emerged as a crucial topic that took on great importance in families' daily lives. As Figure 1 illustrates, each child varied in stance towards contrapuntal lives on both sides of the border and several families experienced a major incident related to their immigration status. For many children, a family member's crossing or deportation became the impetus for more dynamic and frequently articulated stances toward lives inhabitable in Mexico.

\section{[INSERT FIGURE 1]}

Our ethnographic analyses iteratively drew patterns from hundreds of fieldnotes, video logs, transcribed interactions, and transcribed interviews from the larger study. This 
phase of analysis, conducted by Sarah, involved open coding using a qualitative data software program. Working from a subset of codes that emerged around contrapuntal lives, such as "documentation," "immigration," "Mexico vs. US," "separation," "Spanish," "English," and "future," we compiled a case study for each of the seven students, organized under categories such as "Key immigration incident," "Imagined life in Mexico," "Education opportunities and language," and "Migration decisions."

Here we focus on the case of Princess for several reasons. Although children and families regularly articulated imagined transnational lives in Mexico and the US, Princess' father's deportation during the spring of her second grade year brought increased attention and weight to these bifurcated futures (See Gallo, 2014 for an ethnographic analysis of the educational effects of Princess' father's deportation). Although almost half of the seven focal students have dealt with the real possibility of parental deportation since 2011, Princess is the only one who navigated these challenging circumstances during data collection. Thus, tracking Princess' dynamic articulations of contrapuntal childhoods and schooling provides insights into the ways that her positioning of certain imagined futures accumulated as potentially realizable, in turn contributing to family migration decisions.

\section{Findings: Princess and her family}

\section{Princess' Family Pre-Deportation}

Unlike most immigrant parents in Marshall who had arrived to the US in the past decade, Princess' father Federico moved to New York City (NYC) as a child and was a relatively balanced bilingual from his schooling there. He met Princess' mother Cinthia, 
also from Mexico, in NYC and when Princess was a toddler they decided to move to Marshall, Pennsylvania. In the fall of Princess' second-grade year, their second child, Bianca, was born. Federico worked the early shift as a cook in a restaurant, which allowed him to care for Princess and her baby sister in the afternoons and most weekends while Cinthia worked cleaning hotels. Princess' parents were surprised to learn that there were no bilingual education options in Marshall, as they both felt that bilingual classes were superior, and they observed that, unlike her cousins who attended bilingual schools in NYC, Princess did not have facility in translating between Spanish and English. Federico decided that he would begin to teach Princess Spanish literacy in the near future, once their family re-settled into a calmer routine with the new baby (FN 3/5/11). Unlike many immigrant parents in Marshall who regularly considered and often longed for their contrapuntal lives in Mexico, Federico, who had not been to Mexico in 20 years, could not imagine living there.. Prior to his deportation he emphasized, "for living, I don't like Mexico anymore" (FN 3/5/11). Princess had similar sentiments, telling her mom things like, "I don't want to go to your Mexico. Mexico is ugly" and "I'm not going to separate myself from my country (the US). " Despite her mother's assertions that Princess was also mexicana, Princess could not imagine her childhood in Mexico (FN11/05/10). Children from this study demonstrated a wide range of feelings about Mexico. As Figure 1 illustrates, prior to her father's deportation, Princess fell toward one end of the continuum: she regularly voiced her desire to never visit or live there, as well as her fears that life in Mexico would mean forgetting English.

Immigration Policy and Princess' Family LP 
Immediately following her father's detainment, in which he was held for several months in U.S. immigration facilities, Princess was steadfast in her stance that she did not want to live in Mexico. She told her mother that if she decided to go back, then Princess wanted to stay with her tíos and primos (uncles and cousins) in the US. Cinthia teared up when talking about what it would be like for Princess to move to Mexico, as she felt the educational opportunities would not be the same. She worried that if she were to take Princess to Mexico now, she would indeed forget English, as schooling would only occur in Spanish. Federico had proposed a new family language policy, in which he would speak to Princess in 'puro inglés' (solely English) so that she would not forget it, but Cinthia worried that it would not be enough (FN 3/21/11).

By the time Federico was deported to Mexico a few months later, they decided that Cinthia and her daughters would stay in the US for at least five more months so that Princess — who struggled with reading and writing in her English-medium classroom— could develop her English literacy skills. They reasoned that if Princess could read and write in English with ease, she would be more likely to retain it if they returned to Mexico. In Mexico, people often asked Federico why his family had not joined him, and when he explained "porque m'hija está estudiando," ("because my daughter is studying") the response was often "aquí también hay escuelas" ("there are also schools here") (Interview 6/6/11). As they imagined their new lives in Mexico, Cinthia explained that they did not have the money to send Princess to private schools taught in English, and like many Mexican parents considering repatriation, she worried about how Princess would fare in Spanish-only schools in Mexico (Interview 6/6/11). 
As Princess' family navigated their tangible family separation due to immigration practices, they also adapted their family language acquisition planning in terms of Spanish literacy. From what he had heard from speaking to other families with children in local Mexican schools, Federico realized Princess would need to know how to read in Spanish. He encouraged Cinthia to begin teaching Princess the basics, such as the short, common words. Cinthia - who had a 6th grade education in Mexico and was now working additional jobs to make ends meet with her husband's absence, did her best to do this, but progress was slow (FN 8/29/11). Princess had been a reluctant writer in school, yet written letters were one of the few ways that she could correspond with her father once he was detained. She would bubble with excitement each time she received a letter from him, and one afternoon exclaimed how she planned to hang his card and new photo next to her Justin Bieber poster at home. She also started borrowing Sarah's notebook during school to write her father short letters in English, such as "Dear Dad. I love you so much dad." Eventually she started asking Sarah how to spell things in Spanish, such as the word 'querido' (dear) for a letter she was writing to her father, engaging more directly with Spanish literacy practices (FN 5/2/11).

Princess' and Cinthia's navigation of reunification in Mexico or separation if they remained in the US regularly emerged through routine talk, and Princess played an important role in discursively shaping their imagined futures in Mexico and the US. For example, early one spring evening Princess $(\mathbf{P})$ helped her mother Cinthia $(\mathbf{C})$ fold laundry in their shared family bedroom, the popular TV show ICarly playing in English in the background. Her infant-aged sister, Bianca, happily kicked her legs in her Fisher- 
Price swing as Princess jokingly placed her own oversized clothes on Bianca's tiny body. Noting the small size of one of Princess' shirts, the following conversation unfolded ${ }^{1}$ :

1. Cinthia: Esta no te queda, ¿verdad?

This doesn't fit you, right?

2. Princess: No sé.

\section{I don't know.}

3. C: $\quad$ Entonces vamos a guardarlo para la Bianca.

Then we'll save it for Bianca.

4.

$$
\text { ((10 seconds }))
$$

5. $\mathrm{P}$

Papi no va a estar aquí.

Papi won't be here.

6. C: I KNOW.

7. P: Él no va a estar para mi quince.

He won't be at my quinceañera.

8. C: ¿¿Por qué no!?

Why not?!

9. P: Um um.

10. C: ¿La hacemos en México tu quince?

Will we do your quinceañera in Mexico?

11. P: $\quad$ No quiero.

I don't want to.

12. C: WHY NOT? Es más bonito.

WHY NOT? It's more beautiful.

13. P: Um um.

${ }^{1}$ See Appendix for transcript conventions 
14. C: $\quad$ Está más grande. Está como tu bautizo. Como lo hicimos afuera.

It's bigger. It's like your baptism. How we did it outside.

15. P: $\quad \mathrm{Um} \mathrm{hm}$.

16. C: Así es. Así es en México. Las fiestas.

Like that. That's what it's like in Mexico. The parties.

17. P: $\quad$ BUT yo no quiero-guácala.

BUT I don't want that-yuck.

18. C: $\quad$ ¡Pues es grande!

Well it's big!

19. P: Pero yo no quiero ir a México. ¡No quiero hablar en español cada rato!

But I don't want to go to Mexico. I don't want to speak in Spanish constantly.

20. Ya no cuando-Si vinimos para atras para acá. Si vamos a venir para atras Not anymore when - If we came back here, to here. If we come back here

21. ya ni vamos a hablar en inglés.

we won't even speak in English.

22. C: $\quad$ WHY NOT? Lo practicas con tu papá.

WHY NOT? You practice it with your dad.

23. P: Pero él no va a saber.

But he's not going to know.

24: C: $\quad$ Tú sí. La Bianca no va a saber. Tú la vas a enseñar.

You will. Bianca isn't going to know it. You have to teach her.

25. P: $\quad$ HA HA. LOSER! ((To baby)).

(Video Log, 05/14/11).

Here, Princess transformed a quotidian decision about a shirt as a hand-me-down to a contrapuntal consideration of their imagined futures in Mexico or the US, in seven years 
time when the shirt would fit her baby sister and eight year-old Princess would be celebrating a life milestone- her fifteenth birthday or quinceañera (Lines $1-7)$. Through the discussion of her fifteenth birthday, Princess and Cinthia articulated stances on their counterpoint lives, or imagined lives in the US or Mexico, in ways that were deeply entwined with monoglossic ideologies regarding language, place, and educational possibility. It is clear that second-grader Princess played an agentive role in shaping their family language policies and migratory decisions. For example, she proposed a U.S.based celebration that, unfortunately, would not include her exiled father (lines 5, 7). She interpreted her imagined life in Mexico as undesirable: she did not want to partake in yucky Mexican parties (line 17) and did not want to have to speak Spanish constantly, which she feared would cause her to forget English (lines 19- 21, 23). As illustrated through the jocular comment she made to her baby sister about not knowing English if they moved to Mexico (lines 24-25), Princess highly valued knowing English.

Her mother, Cinthia, resisted Princess' deficit positionings of their imagined Mexican lives and monolingual Spanish futures. She instead made claims to a life in Mexico in which they could have a grandiose celebration, and one that Princess' father could attend (lines, $8,10,12,14,16,18)$. And instead of Spanish monolingualism, she proposed a family language policy in which Princess would continue to practice English with her father, who had native-like English resources, and would take on the teacher role with her sister (lines 22, 24), thus creating opportunities for her continual English development in Mexico. In an interview, Cinthia further commented "She [Princess] says that no-that she won't know how to speak English anymore because she is going to learn more Spanish-I tell her no, that she won't forget. And she says yes, she will" 
(6/6/11). For Princess, monoglossic ideologies of language and place undergirded her interpretation and resistance to family language policies. This interaction provides a window into the dynamic ways a young daughter and mother engaged with, resisted, and refashioned family language policies as they navigated difficult decisions regarding transnational schooling or family separation.

After her husband's deportation, Cinthia commented on how she felt like she now talked to eight year-old Princess like an adult, no longer like una niña (a little girl). As Cinthia navigated difficult decisions regarding her family's life in Mexico or the US, she engaged Princess in these conversations and decisions, and through her talk Princess actively contributed to family migration decisions. For example, after her initial stance that she never wanted to move to Mexico, Princess then had a change of heart. She tried to persuade her mother to simply put her in a school in Mexico, arguing it would be the same as their life in Marshall, but united as a family and in Spanish, to which her mother responded that it was not that easy due to the schooling options there (FN 4/1/11). In order to facilitate communication with her father in Mexico once he returned, Princess' family acquired a computer and began videocalls with Cinthia's relatives in Mexico, whom Princess had never seen. Through these visual conversations with her Mexican kin, Princess further began to imagine her life there. For example, one day she excitedly explained she had seen her tía (aunt) in Mexico, who had her exact same short bob haircut. She also spoke with her young cousin who assured her that ICarly was also on TV in Mexico, just in Spanish rather than English (FN 4/25/11). These familiar childhood details made bridges to life in Mexico seem more tenable. 
As they continually navigated these family discussions and decisions, the imperative of biliteracy development emerged. For example, when asked if Princess agreed with the current plan of waiting before deciding to return to Mexico, Cinthia responded,

1. Yes, she says yes. I tell her that you'll go on vacation by yourself and then return. She

2. said, "No. Not right now. We'll go when you [mom] are ready." I say, "Ok. When we're

3. ready. But the only thing I ask of you is that you know how to do everything"

(Interview 6/6/11).

Through this reported conversation between Cinthia and Princess, it is clear that Princess regularly engaged with, resisted, and refashioned family language policy in ways that were deeply tied to educational possibilities and family migration decisions. When her mother suggested that Princess travel alone to Mexico for vacation to visit her father, Princess rejected this plan (lines 1-2). She created an alternative plan that limited further family separation, and entailed them travelling together, once her mother was also ready (line 2). Unspoken in this decision was the shared knowledge that her mother, who, in contrast to Princess did not have U.S. documentation, could not freely cross the U.S.Mexican border, and that their travel there would entail a long-term relocation rather than a short visit. Cinthia agreed to this plan, but highlighted the importance of language acquisition planning in which Princess "know(s) how to do everything." (line 3). In other parts of this interview Cinthia reinforced that this meant that Princess would need to develop her English literacy skills through her U.S. schooling, so that she would not forget English once they move to Mexico. She had told Princess “it won't be so easy to forget it [English] because you know how to write it, you know how to read it" (Interview 6/6/11).. Yet biliteracy criteria that their family agreed to prior to repatriation included 
not only the cultivation of extensive English literacy skills to retain her English repertoires but also foundational Spanish literacy skills to survive a transition to Mexican schooling, biliteracy skills that were not developed in Princess' English-only schooling. In the final section we discuss the implications from these findings.

\section{Implications}

Careful attention to the routine talk of one daughter and mother, as they navigate family separation due to deportation practices and negotiate responsive family language policies to prepare for educational futures on either side of the border, illustrates how articulations and stances on imagined futures accumulate into real-world language and migration decisions. As these findings reveal, these decisions are not only made in a decontextualized, top-down manner by adults, but are also shaped in important ways by children's imagined educational childhoods across transnational contexts. We argue for attention to the dynamic and shifting ways that children discursively contribute to embraceable educational futures across geopolitical borders. These discursive processes have material, real-world implications (Dick, 2013; Orellana, 2009) and this study highlights the important contributions of ethnography of LPP, as it provides a lens to see and understand the complex ways that children contribute to family language policy and migration decisions.

The Ethnography of LPP further reveals the significant ways that monoglossic ideologies undergird families' imagined educational futures across borders and how our current schooling approaches dichotomize rather than support the familial language and literacy resources that transnational students bring to our classrooms or the ones that they will need to further develop for educational success in the US or abroad (Utakis \& Pita, 
2005). On the level of educational policy and practice, these findings highlight the importance of additive bilingual schooling programs that combat monoglossic ideologies and prepare students with bilingual language and literacy resources that are reflective of their bilingual lives in the US or transnationally. There were no additive bilingual education options available in Marshall, a lack sorely felt by Princess' parents as they sought to prepare Princess for the possible move to Mexico necessitated by her father's deportation. Pedagogical, curricular, and assessment policies and practices that open up ideological spaces for valuing multilingualism and implementational spaces for enacting fluid and dynamic multilingual practices, voices and identities would go a long way toward supporting children and families in their pursuit of flexible biliteracy repertoires as they navigate transnational lives across linguistic, cultural, and political borders.

Today's deportation regime (De Genova, 2010), in which families are regularly separated across borders due to our nation's restrictive immigration policies, further point to important questions regarding the role of schooling to prepare children for transnational futures. These findings illustrate that we cannot treat educational and immigration policies as separate (Mangual Figueroa, 2014) and raise challenging questions regarding our responsibilities as educators and policy makers to better prepare children from transnational families for educational success on both sides of the border, especially in the face of unprecedented deportations (Hamann \& Zúñiga, 2011). Yet within schools educators are often unsure of how to broach the topic of immigration practices in their classrooms, and are provided minimal guidance on how to support students who are navigating major life changes due to immigration policies (Gallo, 2014). As educational scholars, we carry important possibilities and responsibilities for bringing 
attention to the educational consequences of immigration policies, and for better preparing educators to understand undocumented status as an axis of difference that merits support for equitable schooling (Gallo \& Link, 2015; Mangual Figueroa, 2014).

In our research, it is clear that the complex interplay of language, biliteracy, schooling, and spaces for belonging are at the forefront of children's and transnational families' decisions regarding family separation or reunification. Our current schooling approaches, which subtract the linguistic and literacy resources that bilingual children bring to school, deeply constrain families' options as they search for promising educational futures for their children. Our findings highlight the importance of making schools more reflective of transnational families' realities and priorities, by opening up ideological and implementational spaces for enhancing rather than undermining the flexible biliterate repertoires their children are well positioned to develop.

\section{Appendix}

Transcript Conventions:

Italics: Translations in English

CAPITAL LETTERS: TEXT ORIGINALLY SPOKEN IN ENGLISH

(( )): Accompanying action

\section{References}

Blackledge, A., \& Creese, A. (Eds.). (2014). Heteroglossia as practice and pedagogy. New York: Springer.

Blommaert, J. (2013). Policy, policing and the ecology of social norms: Ethnographic 
monitoring revisited. International Journal of the Sociology of Language, 219,123140.

Canagarajah, S. (1999). Resisting linguistic imperialism in English teaching. Oxford: Oxford University Press.

Cooper, R. L. (1989). Language planning and social change. Cambridge, UK: Cambridge University Press.

Chaudry, A., Capps, R., Pedroza, J. M., Castanada, R. M., Santos, R., \& Scott, M. M. (2010). Facing our future: Children in the aftermath of immigration enforcement (pp. 1-80). Washington, D.C.: The Urban Institute.

De Genova, N. (2010). The deportation regime: Sovereignty, space, and the freedom of movement. In N. De Genova, \& N. Peutz (Eds.), The deportation regime (pp. 33-65). Durham, NC: Duke University Press.

Dick, H. (2013). Diaspora and Discourse: The Contrapuntal Lives of Mexican Nonmigrants. In Ato Quayson \& Girish Daswani (Eds.), A Companion to diaspora and transnationalism studies (pp. 412-427). Malden, MA: Wiley Blackwell.

Dreby, J. (2010). Divided by borders: Mexican migrants and their children. Berkeley, CA: University of California Press.

Escamilla, K. (2006). Monolingual assessment and emerging bilinguals: A case study in the U.S. In Ofelia García, Tove Skutnabb-Kangas, \& María Torres Guzmán (Eds.), Imagining multilingual schools: Languages in education and glocalization (pp. 184199). Clevedon, UK: Multilingual Matters.

Flores, N., \& Schissel, J. L. (2014). Dynamic bilingualism as the norm: Envisioning a heteroglossic approach to standards-based reform. TESOL Quarterly, 48(3), 454-479. 
Fogle, L. \& King, K.A. (2013). Child agency and language policy in transnational families. Issues in Applied Linguistics, 19(1),1-25.

Gallo, S. (2014). The effects of gendered immigration enforcement on middle childhood and schooling. American Educational Research Journal, 51(3), 473-504.

Gallo, S. \& Link, H. (2015). 'Diles la verdad" : Deportation Policies, Politicized Funds of Knowledge, and Schooling in Middle Childhood. Harvard Educational Review, 85(3), $357-382$.

Gándara, P., \& Hopkins, M. (Eds.). (2010). Forbidden language: English learners and restrictive language policies. New York: Teachers College Press.

García, O. (2009). Bilingual education in the 21st century: A global perspective. Malden, MA: Wiley-Blackwell.

Hamann, E., \& Zúñiga, V. (2011). Schooling and the everyday ruptures transnational children encounter in the United States and Mexico. In C. Coe, R. Reynolds, D. Boehmn, J. Hess, \& H. Rae-Espinoza (Eds.), Everyday ruptures: Children, youth, and migration in global perspective (pp. 141-160). Nashville, TN: Vanderbilt University Press.

Hamann, E., Zúñiga, V., \& Sánchez-García, J. (2010). Transnational students' perspective on schooling in the United States and Mexico: The salience of school experience and country of birth. In M. Ensor \& E. Gozdziak (Eds.), Children and migration: At the crossroads of resiliency and vulnerability (pp. 230-252). NY, NY: Palgrave Macmillan.

Heller, M. (1999). Linguistic minorities and modernity: A Sociolinguistic ethnography. New York: Longman. 
Hornberger, N. H. (1988). Bilingual education and language maintenance: A Southern Peruvian Quechua case. Berlin: Mouton.

Hornberger, N. H. (1990). Creating successful learning contexts for bilingual literacy. Teachers College Record, 92(2), 212-229.

Hornberger, N. H. (2002). Multilingual language policies and the continua of biliteracy: An ecological approach. Language Policy, 1(1), 27-51.

Hornberger, N. H. (Ed.). (2003). Continua of biliteracy: An ecological framework for educational policy, research and practice in multilingual settings. Clevedon, UK: Multilingual Matters.

Hornberger, N. H. (2006). Nichols to NCLB: Local and global perspectives on U.S. language education policy. In O. García, T. Skutnabb-Kangas, \& M. Torres-Guzmán (Eds.), Imagining multilingual Schools: Languages in education and Globalization (pp. 223-237). Clevedon, UK: Multilingual Matters.

Hornberger, N. H. (2013). Negotiating methodological rich points in the ethnography of language policy. International Journal of the Sociology of Language, 219, 101-122.

Hornberger, N. H., \& Johnson, D. C. (2007). Slicing the onion ethnographically: Layers and spaces in multilingual language education policy and practice. TESOL Quarterly, 41(3), 509-532.

Hornberger, N. H., \& Johnson, D. C. (2011). The ethnography of language policy. In T. McCarty (Ed.), Ethnography and language policy (pp. 273-289). New York: Routledge.

Hornberger, N. H., \& Link, H. (2012). Translanguaging and transnational literacies in multilingual classrooms: A biliteracy lens. International Journal of Bilingual 
Education and Bilingualism, 15(3), 261-278.

Jaffe, A. (1999). Ideologies in action: Language politics on Corsica. Berlin: Mouton.

Johnson, D. C. (2013). Introduction: Ethnography of language policy. International Journal of the Sociology of Language, 219, 1-6.

King, K., \& Rambow, A. (2012). Transnationalism, migration, and language education policy. In B. Spolsky (Ed.), The Cambridge handbook of language policy (pp. 399-417). NY, NY: Cambridge University Press.

Kohli, A., Markowitz, P. L., \& Chavez, L. (2011). Secure communities by the numbers: An analysis of demographics and due process. University of California, Berkeley: The Chief Justice Early Warren Institute On Law and Social Policy.

Makoni, S., \& Pennycook, A. (Eds.). (2007). Disinventing and reconstituting languages. Clevedon, UK: Multilingual Matters.

Mangual Figueroa, A. (2014). Finding a place: Migration and education in mixed-status families. In P. Portes., S. Salas,. P. Mellom (Eds.), U.S. Latinos and education policy: Research-based directions for change (pp. 149-172). NY, NY: Routledge.

Menken, K. (2008). English learners left behind: Standardized testing as language policy. Clevedon, UK: Multilingual Matters.

Orellana, M. F. (2009). Translating childhoods: Immigrant youth, language, and culture. New Brunswick, NJ: Rutgers University Press.

Passel, J., Cohn, D., \& Gonzalez-Barrera, A. (2012). Net migration from Mexico falls to zero-and perhaps less. Washington, D.C.: The Pew Hispanic Research Center. 
Preston, J. (2012, September 7, 2012). "Record number of foreigners were deported in 2011, officials say". Retrieved from http://www.nytimes.com/2012/09/08/us/usdeports-record-number-of-foreigners-in-2011.html?_r=0

Ruiz, R. (1984). Orientations in language planning. NABE Journal, 8(2), 15-34.

Said, E. (2000). Reflections on exile. In Edward Said (Ed.), Reflections on exile and other essays (pp. 173-186). Cambridge, MA: Harvard University Press.

Sánchez-García, J, Hamann, E, \& Zúñiga, V. (2012). What the youngest transnational students have to say about their transition from U.S. schools to Mexican ones. Diaspora, Indigenous, and Minority Education, 6, 157-171.

Schiffman, H. F. (1996). Linguistic culture and language policy. New York: Routledge.

Suárez-Orozco, C., Yoshikawa, H., Teranishi, R. T., \& Suárez-Orozco, M. (2011). Growing up in the shadows: The developmental implications of unauthorized status. Harvard Educational Review, 81(3), 438-472.

Tollefson, J. W. (1991). Planning language, planning inequality: Language policy in the community. London: Longman.

Utakis, S., \& Pita, M. (2005). An educational policy for negotiating transnationalism: The Dominican community in New York City. In A. S. Canagarajah (Ed.), Reclaiming the local in language policy and practice (pp. 147-164). Mahwah, NJ: Lawrence Erlbaum.

Valenzuela, A. (1999). Subtractive Schooling: U.S.-Mexican Youth and the Politics of Caring. Albany, NY: SUNY Press.

Wessler, S. (2012, December 17). Nearly 205K deportations of parents of U.S. citizens in just over two years. Retrieved from http://www.colorlines.com/archives/2012/12/us_deports_more than_200k_parents.html 